\title{
FAKTOR-FAKTOR YANG MEMENGARUHI PENGUNGKAPAN TANGGUNG JAWAB SOSIAL PADA PERUSAHAAN DIBIDANG PERTAMBANGAN YANG TERDAFT AR DI BURSA EFEK INDONESIA
}

\author{
Gracia Gunawan \\ Prima Apriwenni*
}

\author{
Program Studi Akuntansi, Institut Bisnis dan Informatika Kwik Kian Gie, \\ Jl. Yos Sudarso Kav. 87, Jakarta 1435
}

\begin{abstract}
In the company's efforts to achieve profit, companies often pay less attention to the impact of their activities. This matter can cause global warming. To prevent these problems, the law is issued that requires every company to do some activities that are environmentally friendly. This activity is expressed throuth the corporate social responsibility disclosure. The purpose of this research to test whether profitability, liquidity, leverage, and media exposure have a positive influence to corporate social responsibility disclosure. The object of this research is a mining company listed in Indonesia Stock Exchange year 2014-2016 with the unit observation is annual financial statements with a total sample of a company is 36 companies. The research method used is observation method with an observation to company data. Based on test results, liquidity and media exposure significantly influence CSR disclosure, while profitability and leverage had no significant influence to CSR disclosure.
\end{abstract}

Keyword: Corporate Social Responsibility, Disclosure, Profitability, Liquidity, Leverage, Media Exposure.

\begin{abstract}
ABSTRAK
Dalam usaha perusahaan untuk mencapai laba, seringkali perusahaan kurang memerhatikan dampak dari aktivitasnya. Hal ini dapat menyebabkan global warming. Untuk menanggulangi masalah tersebut, maka dikeluarkanlah Undang-Undang yang mewajibkan setiap perusahaan melakukan kegiatan / aktivitas yang ramah lingkungan. Kegiatan ini diungkapkan melalui luas pengungkapan tanggung jawab sosial perusahaan. Penelitian ini bertujuan untuk menguji apakah Profitabilitas, Likuiditas, Leverage dan Media Exposure memiliki pengaruh yang positif terhadap luas pengungkapan tanggung jawab sosial. Objek penelitian ini adalah perusahaan dibidang pertambangan yang terdaftar di Bursa Efek Indonesia periode 2014-2016 dengan unit amatan laporan keuangan tahunan dengan total sampel perusahaan yaitu 36 perusahaan. Metode penelitian yang digunakan adalah metode observasi yaitu pengamatan terhadap data-data perusahaan. Berdasarkan hasil pengujian, variabel likuiditas dan media exposure berpengaruh signifikan terhadap pengungkapan CSR sedangkan variabel profitabilitas dan leverage tidak berpengaruh secara signifikan terhadap pengungkapan CSR.
\end{abstract}

Kata Kunci: Pengungkapan Tanggung Jawab Sosial, Profitabilitas, Likuiditas, Leverage, Media Exposure.

*Alamat kini: Institut Bisnis dan Informatika Kwik Kian Gie, Jl. Yos Sudarso Kav 87, Sunter, Jakarta 14350

Penulis untuk Korespondensi: (021) 65307062 Ext. 708. Email: prima.apriwenni@kwikkiangie.ac.id 


\section{Pendahuluan}

\section{Latar Belakang}

Pada era jaman sekarang ini, perkembangan dunia bisnis yang semakin meluas mengakibatkan adanya persaingan yang ketat antar perusahaan. Tujuan utama dari setiap perusahaan adalah mendapatkan laba atau keuntungan yang semaksimal mungkin dengan biaya yang minimum. Dalam usahanya, seringkali perusahaan kurang memperhatikan dampak dari aktivitasnya, seperti misalnya dampak sosial dan lingkungan yang memicu terjadinya konflik sosial. Akibatnya, seringkali munculnya demonstrasi dan protes dari penduduk sekitar yang menyiratkan ketidakpuasan atas pengelolaan perusahaan. Untuk menanggulangi kerusakan lingkungan yang diakibatkan oleh perusahaan, maka dikeluarkanlah Undang-Undang Republika Indonesia No. 40 Tahun 2007 tentang Perseroan Terbatas. Adapun pada pasal 74 berbunyi "Perseroan yang menjalankan kegiatan usahanya di bidang dan/atau berkaitan dengan sumber daya alam wajib melaksanakan Tanggung Jawab Sosial dan Lingkungan."

Istilah Corporate Social Responsibility (selanjutnya akan disebut sebagai CSR) mulai dikenal pada tahun 1970-an. Menurut Untung (2009), CSR adalah komitmen perusahaan atau dunia bisnis untuk berkontribusi dalam pengembangan ekonomi yang berkelanjutan dengan memperhatikan tanggung jawab sosial perusahaan dan menitikberatkan pada keseimbangan antara perhatian terhadap aspek ekonomis, sosial, dan lingkungan. Makna dari tanggung jawab sosial perusahaan berarti terdapat kewajiban bertanggung jawab atas perintah Undang-Undang yang berlaku dan memberikan ganti rugi terhadap pihak-pihak yang dirugikan baik secara langsung maupun tidak langsung.

Salah satu jenis perusahaan yang dimaksud adalah perusahaan pertambangan. Perusahaan pertambangan adalah perusahaan yang bergerak di bidang penambangan dan merupakan salah satu sumber daya terbesar di dunia. Salah satu hasil penambangannya adalah mineral, batubara, panas bumi, migas, dan sebagainya. Kegiatan pertambangan ini diatur dalam Undang-Undang No. 11 Tahun 1967 tentang Ketentuan-Ketentuan Pokok Pertambangan. Sektor pertambangan ini memiliki kontribusi besar terhadap berbagai aspek mulai dari penanaman modal asing hingga menambah jumlah lapangan pekerjaan. Namun, menurut Wahana Lingkungan Hidup Indonesia (WALHI) menilai bahwa perusahaan pertambangan merupakan perusahaan yang kegiatan utamanya memiliki dampak sosial lingkungan yang memiliki pengaruh langsung terhadap sumber daya alam yang dalam kegiatannya memiliki kemungkinan besar untuk melakukan kerusakan terhadap lingkungan apabila tujuan perusahaan hanya mementingkan keuntungan saja (Fibrianti \& Wisada, 2015).

Sebagai contohnya adalah adanya kasus penambangan pasir illegal yang terjadi di Lumajang, Jawa Timur. Terjadi kerusakan di sepanjang pesisir Pantai Watu Pecak, Desa Selok Awar Awar, Pasirian karena terhampar pasir hitam berkilauan. Pengerukan pasir yang dilakukan setiap hari selama dua tahun lebih mengakibatkan adanya lubang seluas lapangan sepak bola sedalam empat meter. Para warga sekitar yang awalnya berprofesi sebagai petani beralih menjadi pencari kerang semenjak sawah yang mereka miliki rusak. (www.benarnews.org)

Penelitian mengenai pengungkapan tanggung jawab sosial pada laporan tahunan perusahaan dan faktor-faktor yang mempengaruhinya, merupakan hal yang penting untuk dilakukan. Bagi perusahaan yang menjalankan praktik akuntansi dan pengungkapan atas tanggung jawab sosialnya diyakini dapat memberikan nilai tambah dari para stakeholdernya. Adapun penelitian mengenai faktor-faktor yang mempengaruhi pengungkapan tanggung jawab sosial antara lain dengan variabel: dewan komisaris, kinerja lingkungan, hutang, kepemilikan saham, likuiditas, profitabilitas, leverage, ukuran perusahaan, media exposure, dan lain sebagainya.

Menurut Maiyarni et al (2014), likuiditas perusahaan menunjukkan kemampuan perusahaan dalam menjaga aktivitas operasional. Dapat dikatakan likuiditas mencerminkan kesehatan suatu perusahaan. Tingkat dimana perusahaan dapat dengan cepat memenuhi kewajiban lancarnya dari aktiva lancar atau kemampuan usaha untuk memenuhi kewajiban jangka pendek. Melalui likuiditas dapat dipandang kinerja manajemen dalam mengelola keuangan perusahaan. Oleh karena itu dapat dikatakan bahwa likuiditas berpengaruh positif terhadap pengungkapan tanggung jawab sosial perusahaan. Hal ini juga senada dengan Silaen (2013) yang menyatakan bahwa likuiditas berpengaruh secara positif terhadap pengungkapan tanggung jawab 
sosial perusahaan. Sedangkan menurut Yuliansyah (2017) mereka menyimpulkan bahwa likuiditas tidak berpengaruh terhadap pengungkapan tanggung jawab sosial perusahaan, sehingga semakin tinggi atau rendahnya rasio likuiditas tidak memiliki pengaruh terhadap kinerja perusahaan.

Profitabilitas merupakan salah satu bagian finansial yang berpengaruh terhadap nilai perusahaan. Profitabilitas menunjukkan tingkat keuntungan bersih yang mampu diraih oleh perusahaan saat menjalankan operasinya. Para pemegang saham selalu menginginkan keuntungan dari investasi yang mereka tanamkan pada perusahaan, keuntungan tersebut diperoleh dari keuntungan setelah bunga dan pajak. Semakin besar keuntungan yang diperoleh semakin besar kemampuan perusahaan untuk membayarakan devidennya, sehingga akan semakin banyak investor yang berinvestasi pada perusahaan tersebut. Dengan demikian dapat dikatakan bahwa profitabilitas berdampak positif terhadap tingkat pengungkapan tanggung jawab sosial perusahaan. Hal ini juga senada dengan penelitian yang dilakukan oleh Kamil \& Herusetya (2012) dan Rindawati (2015) menyatakan bahwa profitabilitas memiliki pengaruh positif yang signifikan terhadap pengungkapan tanggung jawab sosial karena perusahaan yang mampu menghasilkan profit adalah perusahaan yang memiliki manajemen yang mengerti dan peduli terhadap lingkungan sekitar. Sebaliknya menurut Saripudin (2011) yang menyatakan tidak terdapat hubungan yang signifikan antara profitabilitas dengan luas pengungkapan tanggung jawab sosial.

Leverage merupakan tolak ukur aktivitas perusahaan yang dibiayai oleh hutang. Jika suatu perusahaan memiliki rasio hutang diatas modal, maka perusahaan cenderung akan mengungkapkan lebih banyak informasi dalam laporan keuangan dibandingkan dengan perusahaan yang memiliki tingkat rasio yang rendah. Leverage dalam penelitian Maiyarni et al (2014) mempengaruhi secara signifikan pegungkapan tanggung jawab sosial. Sedangkan menurut Wijaya (2012) leverage tidak memiliki pengaruh yang signifikan terhadap luas pengungkapan tanggung jawab sosial dikarenakan semakin tinggi tingkat leverage, maka perusahaan cenderung mengurangi pengunggkapan tanggung jawab sosial sehingga tidak menjadi sorotan dari para debtholders.

Pada umumnya, perusahaan menggunakan laporan sosial (social report), laman (web), dan juga dengan iklan untuk mengkomunikasikan program CSR yang dilakukannya. Di dalam penelitian Wahyutama (2016), ia menyatakan bahwa media exposure mempunyai pengaruh yang signifikan terhadap pengungkapan luas tanggung jawab sosial. Pemanfaatan pengungkapan luas tanggung jawab sosial melalui website resmi perusahaan dapat meningkatkan reputasi perusahaan. Hasil penelitian ini juga sama dengan hasil penelitian yang dilakukan oleh Soraya (2016). Lain pula dengan penelitian yang dilakukan oleh Nur \& Priantinah (2012) yang mengungkapkan bahwa media exposure tidak berpengaruh terhadap pengungkapan luas tanggung jawab sosial.

Berdasarkan penelitian-penelitian sebelumnya, maka peneliti tertarik untuk menguji kembali faktor-faktor yang terkait dengan pengungkapan tanggung jawab sosial yang telah digunakan pada penelitian terdahulu, yaitu profitabilitas, likuiditas, leverage, dan Media Exposure. Penelitian ini dilakukan untuk data pada periode tahun 2014-2016

\section{Batasan Masalah}

1. Apakah profitabilitas berpengaruh positif terhadap luas pengungkapan tanggung jawab sosial ?

2. Apakah likuiditas berpengaruh positif terhadap luas pengungkapan tanggung jawab sosial ?

3. Apakah leverage berpengaruh positif terhadap luas pengungkapan tanggung jawab sosial ?

4. Apakah media exposure berpengaruh positif terhadap luas pengungkapan tanggung jawab sosial ?

\section{Tujuan Penelitian}

1. Untuk mengetahui apakah profitabilitas berpengaruh positif terhadap luas pengungkapan tanggung jawab sosial.

2. Untuk mengetahui apakah likuiditas berpengaruh positif terhadap luas pengungkapan tanggung jawab sosial.

3. Untuk mengetahui apakah leverage berpengaruh positif terhadap luas pengungkapan tanggung jawab sosial.

4. Untuk mengetahui apakah media exposure berpengaruh positif terhadap luas pengungkapan tanggung jawab sosial. 


\section{Manfaat Penelitian}

1. Bagi Perusahaan

Sebagai informasi bagi perusahaan pertambangan mengenai pentingnya pengungkapan tanggung jawab sosial dan kegiatan yang dilakukannya untuk menjaga ekosistem lingkungan.

2. Bagi Peneliti

Menambah wawasan pengetahuan peneliti mengenai faktor-faktor yang memengaruhi luas pengungkapan tanggung jawab sosial dan juga mengetahui relevansi dan reliabilitas penelitian terdahulu.

3. Bagi Peneliti Selanjutnya

Sebagai acuan untuk penelitian-penelitian berikutnya untuk lebih memperdalam dan memperluas lagi faktor-faktor yang memengaruhi luas pengungkapan tanggung jawab sosial.

\section{Landasan Teori}

\section{Teori Legitimasi}

Pengertian legitimasi menurut Dowling \& Pfeffer (1975) adalah:

"appraisal of action in terms of shared or common values in the context of the involvement of the action in the social system."

Menurut Reverte (2009) menyatakan bahwa teori legitimasi merupakan suatu gagasan tentang kontrak sosial dimana perusahaan setuju untuk melakukan tindakan sosial sehingga perusahaan dapat diterima oleh masyarakat dan dapat memenuhi tujuan perusahaan sehingga kelangsungan hidup perusahaan terjamin. Teori legitimasi mengisyaratkan bahwa perusahaan hendaknya mengurangi expectation gap dengan masyarakat sekitar guna meningkatkan legitimasi (pengakuan) masyarakat. Oleh karena itu, perusahaan hendak menjaga reputasinya, yaitu dengan menggeser pola orientasi (tujuan) yang semula semata-mata diukur dengan economic measurement yang cenderung shareholder orientation, ke arah memperhitungkan faktor sosial sebagai wujud kepedulian dan keberpihakan terhadap masalah sosial kemasyarakatan (stakeholder orientation). Perusahaan perlu menjaga legitimasi stakeholder serta mendudukkannya dalam kerangka kebijakan dan pengambilan keputusan, sehingga dapat mendukung dalam pencapaian tujuan perusahaan, yaitu stabilitas usaha dan jaminan going concern.

\section{Teori Stakeholder}

Pengertian stakeholder menurut Hummels (1998) adalah:

“...(stakeholder are) individuals and groups who have a legitimate claim on the organization to participate in the decision-making process simply because they are affected by the organization's practices, policies and actions."

Tamba (2011) mengatakan bahwa stakeholder theory menyatakan perusahaan bukanlah entitas yang hanya beroperasi untuk kepentingannya sendiri namun harus memberikan manfaat bagi stakeholder-nya (pemegang saham, kreditur, konsumen, supplier, pemerintah, masyarakat, analis, dan pihak lain). Dengan demikian, keberadaan suatu perusahaan sangat dipengaruhi oleh dukungan yang diberikan oleh stakeholder kepada perusahaan tersebut. Secara teoretis perusahaan besar tidak akan lepas dari tekanan. Di samping itu, perusahaan yang lebih besar dengan aktivitas operasi dan pengaruh yang lebih besar terhadap masyarakat mungkin akan memiliki pemegang saham yang memperhatikan program sosial yang dibuat perusahaan sehingga pengungkapan tanggung jawab sosial perusahaan akan semakin luas. Dari sisi tenaga kerja, dengan semakin banyaknya jumlah tenaga kerja dalam suatu perusahaan, maka tekanan pada pihak manajemen untuk memperhatikan kepentingan tenaga kerja akan semakin besar. Program berkaitan dengan tenaga kerja yang merupakan bagian dari tanggung jawab sosial perusahaan, akan semakin banyak dilakukan oleh perusahaan. Hal ini berarti bahwa program tanggung jawab sosial perusahaan juga semakin banyak dan akan diungkapkan dalam laporan tahunan (Sembiring, 2005).

\section{Teori Keagenan}

Jensen dan Meckling (1976) mendefinisikan hubungan keagenan sebagai kontrak yang melibatkan satu orang atau lebih (principals) dan orang lain (agen) untuk melakukan beberapa layanan yang mencakup pendelegasian sebagian wewenang pengambilan keputusan kepada agen. Berdasarkan teori keagenan, perusahaan yang menghadapi biaya pengawasan dan biaya kontrak 
yang rendah cenderung akan melaporkan laba bersih rendah atau dengan kata lain akan mengeluarkan biaya-biaya untuk kepentingan manajemen salah satunya biaya yang dapat meningkatkan reputasi perusahaan di mata masyarakat. Kemudian sebagai wujud pertanggungjawaban, manajer sebagai agen akan berusaha memnuhi seluruh keinginan pihak prinsipal dengan melakukan corporate environmental disclosure sebagai tindakan CSR. Corporate environmental disclosure merupakan sinyal yang dapat mengalihakn perhatian pemegang saham dari pengawasan manipulasi laba atau isu-isu lainnya dan sebagai hasilnya harga saham di pasar modal akan meningkat seiring meningkatnya kepercayaan pemegang saham terhadap transparansi informasi yang diungkapkan oleh perusahaan (Rokhlinasari, 2016).

\section{Teori Kecenderungan Pengungkapan}

Gray et al. (1995) mengemukakan berbagai teori untuk menjelaskan kecenderungan pengungkapan sosial dalam tiga kelompok utama yaitu (1) Decisions Usefulness Studies, (2) Economic Theory Studies, dan (3) Social and Political Theory Studies. Dengan melakukan pengungkapan CSR perusahaan akan mendapatkan timbal balik yang positif dari para stakeholder berupa peningkatan reputasi perusahaan serta pengambilan keputusan pemangku kepentingan berupa,membeli saham, memberikan pinjaman modal, dan membeli produk, sehingga akan memperbaiki kinerja perusahaan termasuk kinerja keuangan. Merakati menyatakan bahwa perusahaanmelakukan pengungkapan Corporate Social Responsibility dengan harapan dapat meningkatkan reputasi dan nilai perusahaan (Merakati, 2016).

\section{Tanggung Jawab Sosial Perusahaan}

Menurut Wibisono (2016), Corporate Social Responsibility (CSR) atau Tanggung Jawab Sosial Perusahaan adalah tanggung jawab perusahaan kepada para pemangku kepentingan untuk berlaku etis, meminimalkan dampak negatif dan memaksimalkan dampak positif yang mencakup aspek ekonomi sosial dan lingkungan (triple bottom line) dalam rangka mencapai tujuan pembangunan berkelanjutan. Istilah triple bottom line dipopulerkan oleh John Elkington pada tahun 1997. Istilah ini mengacu pada 3P yaitu Profit, People, dan Planet. Menurut Harahap (2001), terdapat tiga bentuk tanggung jawab sosial perusahaan yaitu (1) Corporate Philanthropy tanggung jawab perusahaan berada pada sebatas kedermawanan atau kerelaan, belum sampai pada tanggung jawabnya; (2) Corporate Responsibility - kegiatan pertanggungjawaban sudah merupakan bagian dari tanggung jawab perusahaan; dan (3) Corporate Policy - tanggung jawab sosial perusahaan sudah merupakan bagian dari kebijakannya.

\section{Global Reporting Initiative (GRI)}

Global Reporting Initiative (GRI) adalah sebuah organisasi internasional independen yang membantu bisnis, pemerintah, dan organisasi lainnya untuk memahami dan mengkomunikasikan dampak bisnis pada isu-isu keberlanjutan penting seperti perubahan iklim, hak asasi manusia, korupsi, dan yang lainnya. Indikator pengungkapan tanggung jawab sosial menurut GRI terdiri dari 3 indikator, yaitu indikator kinerja ekonomi, indikator kinerja lingkungan dan indikator kinerja sosial. Aspek kinerja ekonomi meliputi kinerja ekonomi, keberadaan pasar, praktek pengadaan dan dampak ekonomi tidak langsung. Kinerja lingkungan meliputi bahan baku, air, energi, keanekaragaman hayati, emisi, efluen dan limbah, transportasi, produk dan jasa, kepatuhan, lain-lain, asesmen pemasok atas lingkungan, dan mekanisme pengaduan lingkungan. Indikator kinerja sosial berhubungan dengan ketenagakerjaan, hak asasi manusia, masyarakat dan tanggung jawab produk. Di dalam hal ketenagakerjaan aspek yang dinilai yaitu kepegawaian, hubungan industrial, kesehatan dan keselamatan kerja, pelatihan dan pendidikan, keberagaman dan kesetaraan peluang, dan kesempatan setara (G4 Guidelines, 2013).

\section{Pengaruh Profitabilitas terhadap Pengungkapan Tanggung Jawab Sosial}

Tingkat profitabilitas yang konsisten akan menjadi tolak ukur bagaimana perusahaan mampu bertahan dalam bisnisnya dengan memperoleh return yang memadai dengan resikonya. Profitabilitas yang tinggi menandakan bahwa kelangsungan hidup perusahaan dapat bertahan untuk jangka waktu yang panjang. Perusahaan yang mempunyai profitabilitas tinggi akan memiliki lebih banyak sumber daya untuk berinvestasi dalam kinerja sosial sehingga tingkat pengungkapan pun cenderung akan semakin luas pula. Kamil dan Herusetya (2012) berpendapat 
bahwa tingkat profitabilitas yang semakin besar menunjukkan perusahaan mampu mendapatkan laba yang semakin besar, sehingga perusahaan mampu untuk meningkatkan aktvitas tanggung jawab sosial, serta mengungkapkan tanggung jawab sosialnya dalam laporan tahunan dengan lebih luas. Sedangkan penelitian Saripudin (2011) menunjukkan bahwa tidak adanya pengaruh yang signifikan terhadap luas pengungkapan tanggung jawab sosial.Oleh karena itu, peneliti ingin mencoba meneliti dengan menggunakan ROA apakah terdapat pengaruh yang positif atau tidak antara profitabilitas dengan luas pengungkapan tanggung jawab sosial perusahaan.

Ha1: Profitabilitas berpengaruh positif terhadap luas pengungkapan tanggung jawab sosial.

\section{Pengaruh Likuiditas terhadap Pengungkapan Tanggung Jawab Sosial}

Likuiditas adalah kemampuan suatu perusahaan untuk memenuhi kewajiban finansialnya karena berkaitan dengan investasi jangka pendek. Tingkat likuiditas yang tinggi akan menunjukkan kuatnya kondisi keuangan perusahaan. Perusahan dengan kondisi seperti ini cenderung akan melakukan pengungkapan informasi yang lebih luas kepada pihak luar karena ingin menunjukkan bahwa perusahaan itu kredibel. Menurut Maiyarni et al (2014), tingkat likuiditas berpengaruh negatif signifikan terhadap pengungkapan tanggung jawab sosial sedangkan menurut Yuliansyah (2017) menyatakan bahwa tingkat likuiditas tidak memengaruhi luas pengungkapan tanggung jawab sosial. Oleh karena itu, peneliti ingin mencoba meneliti dengan menggunakan Current Ratio apakah terdapat pengaruh yang positif atau tidak antara likuiditas dengan luas pengungkapan tanggung jawab sosial perusahaan.

\section{Ha2: Likuiditas berpengaruh positif terhadap luas pengungkapan tanggung jawab sosial.}

\section{Pengaruh Leverage terhadap Pengungkapan Tanggung Jawab Sosial}

Rasio leverage merupakan proporsi antara total hutang terhadap ekuitas pemegang saham. Dengan adanya tingkat leverage yang tinggi, kreditur mampu mengukur kinerja perusahaan dan tidak ada keraguan terhadap hak-hak mereka karena kebutuhan informasi yang dibutuhkan mencukupi dan luas cakupannya. Menurut Maiyarni et al (2014), leverage berpengaruh secara signifikan terhadap luas pengungkapan tanggung jawab sosial perusahaan, sedangkan menurut Wijaya (2012), leverage tidak memengaruhi luas pengungkapan tanggung jawab sosial secara signifikan. Oleh karena itu, peneliti ingin mencoba meneliti dengan menggunakan DER apakah terdapat pengaruh yang positif atau tidak antara leverage dengan luas pengungkapan tanggung jawab sosial perusahaan.

\section{Ha3: Leverage berpengaruh positif terhadap} luas pengungkapan tanggung jawab sosial.

\section{Pengaruh Media Exposure terhadap Pengungkapan Tanggung Jawab Sosial}

Media mempunyai peran sebagai sarana perusahaan untuk mendorong manajemen melakukan pengungkapan CSR. Media merupakan pusat perhatian masyarakat luas mengenai sebuah perusahaan. Media adalah sumber daya pada informasi lingkungan. Pengkomunikasian CSR melalui media akan meningkatkan reputasi perusahaan di mata masyarakat sesuai dengan teori legitimasi yang menjelaskan bahwa perusahaan beroperasi dalam lingkungan eksternal yang berubah secara konstan dan perusahaan berusaha meyakinkan bahwa perilaku mereka sesuai dengan batas-batas dan norma masyarakat. Perusahaan dapat mengungkapkan aktivitas corporate social responsibility melalui berbagai media (Fahmi, 2015). Menurut Wahyutama (2016) terdapat hubungan positif antara media exposure terhadap pengungkapan luas tanggung jawab sosial. Hal ini juga didukung oleh penelitian yang dilakukan oleh Soraya (2016) yang juga menyatakan bahwa media exposure berpengaruh signifikan terhadap pengungkapan luas tanggung jawab sosial. Sedangkan menurut Nur dan Priantinah (2012) diungkapkan hasil penelitiannya bahwa media exposure tidak berpengaruh terhadap luas pengungkapan tanggung jawab sosial. Oleh karena itu, peneliti ingin mencoba meneliti dengan menggunakan dummy apakah terdapat pengaruh yang positif atau tidak antara media exposure dengan luas pengungkapan tanggung jawab sosial perusahaan. 
Ha4 : Media Exposure berpengaruh positif terhadap luas pengungkapan tanggung jawab sosial.

\section{Metode Penelitian}

Objek penelitian yang digunakan adalah perusahaan pertambangan yang terdaftar di Bursa Efek Indonesia (BEI) selama periode 2014 - 2016. Dalam memilih objek penelitian, penulis menggunakan data informasi dalam pengelompokan dengan melihat sektor pertambangan yang tercantum pada Indonesia Capital Market Directory (ICMD) untuk tahun 2014 sampai dengan tahun 2016.

Perusahaan yang memenuhi kriteria dalam penelitian ini adalah 12 perusahaan yang terdaftar di Bursa Efek Indonesia periode 2014-2016 dari total 43 perusahaan.

\section{Variabel Penelitian}

Variabel penelitian yang digunakan dalam penelitian ini adalah:

1. Variabel Dependen

Variabel dependen dalam penelitian ini adalah luas pengungkapan tanggung jawab sosial (CSRD). Variabel ini dihitung dengan menggunakan indeks pengungkapan sosial yaitu dengan teknik checklist dengan melihat pengungkapan informasi sosial pada tema ekonomi, lingkungan, hak asasi manusia, sosial, pertanggung jawaban produk, dan tenaga kerja untuk setiap perusahaan sampel. Enam kategori tersebut terbagi dalam 91 item pengungkapan, sesuai dengan GRI Guidelines yang berlaku.

$$
C S R D=\frac{\sum \text { informasi sosial yang diungkapkan }}{\text { item pengungkapan sosial }}
$$

2. Variabel Independen

a. Profitabilitas

Indikator yang digunakan untuk mengetahui tingkat profitabilitas suatu perusahaan dalam penelitian ini adalah return on asset (ROA). Analisis ROA mengukur kemampuan perusahaan dalam menghasilkan laba dengan menggunakan total aset yang ada setelah disesuaikan dengan biaya-biaya untuk mendanai aset tersebut. ROA dapat dihitung dengan menggunakan rumus berikut:

b. Likuiditas

$$
R O A=\frac{\text { Net Income }}{\text { Total Assets }}
$$

Variabel likuiditas diukur dengan menggunakan Current Ratio, yaitu aset lancar dibagi dengan hutang lancar. Apabila perusahaan mampu memenuhi kewajibannya, maka dikatakan perusahaan tersebut dalam keadaan likuid. Current ratio dapat dihitung dengan menggunakan rumus berikut:

$$
C R=\frac{\text { Current Assets }}{\text { Current Liabilities }}
$$

c. Leverage

Leverage merupakan tingkat risiko dimana penggunaan dana tetap (hutang) yang digunakan untuk mendapatkan pendapatan yang bertujuan untuk meningkatkan nilai perusahaan. Variabel ini diukur dengan menggunakan Debt to Equity Ratio (DER), yaitu total hutang dibagi dengan total kepemilikan modal. DER dapat dihitung dengan menggunakan rumus berikut:

$$
D E R=\frac{\text { Total Liabilities }}{\text { Total Equity }}
$$

d. Media Exposure

Dengan adanya media, perusahaan dapat membagikan informasi yang penting untuk dipublikasikan. Didalam penelitian ini, pengungkapan media diukur dengan menggunakan variabel dummy. Dimana jika perusahaan mengungkapkan kegiatan CSR pada website perusahaan maka diberi kode 1, sedangkan jika perusahaan tidak mengungkapkan CSR pada website perusahaan akan diberikan kode 0 .

\section{Hasil Dan Pembahasan}

\section{Statistik Deskriptif}

Hasil uji statistik deskriptif dapat dilihat dari tabel 2 pada lampiran. 
Berdasarkan tabel 1, hasil analisis dengan menggunakan statistik deskriptif dengan SPSS dapat diketahui hasilnya bahwa:

a. Variabel luas pengungkapan tanggung jawab sosial (CSRD) memiliki nilai tertinggi 0,5934, nilai terendah 0,0440, nilai standar deviasi 0,1503716 , dan nilai rata-rata 0,155983 yang berarti data CSRD tersebar dan paling lazim pada angka 0,1503716.

b. Variabel profitabilitas (ROA) memiliki nilai tertinggi 0,1363 , nilai terendah 0,7842 , nilai standar deviasi 0,1578043 , dan nilai rata-rata $-0,032186$ yang berarti data ROA tersebar dan paling lazim pada angka 0,1578043 .

c. Variabel likuiditas (CR) memiliki nilai tertinggi 20,1675, nilai terendah 0,2656 , nilai standar deviasi 4,0746654, dan nilai rata-rata 2,587411 yang berarti data $\mathrm{CR}$ tersebar dan paling lazim pada angka 4,0746654.

d. Variabel leverage (DER) memiliki nilai tertinggi 3,5614, nilai terendah 0,0425, nilai standar deviasi 0,7333369 , dan nilai rata-rata 0,992155 yang berarti data DER tersebar dan paling lazim pada angka 0,7333369 .

e. Variabel media exposure (ME) memiliki nilai standar deviasi 0,478 , dan nilai rata-rata 0,67 yang berarti data $67 \%$ perusahaan yang dijadikan sampel, mengungkapkan CSRnya melalui media.

\section{Uji Kesamaan Koefisien (Pooling Test)}

Pengujian kesamaan koefisien didalam penelitian ini menggunakan metode the dummy variable approach yang menggunakan dummy tahun. Hasil uji kesamaan koefisien menunjukkan nilai sig. dummy tahun dan variabel independen yang dikalikan dengan dummy tahun $>0,05$ yang artinya bahwa tidak terdapat perbedaan koefisien sehingga data dapat di pooling. Tabel pengujian kesamaan koefisien dapat dilihat pada tabel 3 lampiran.

\section{Uji Asumsi Klasik}

\section{a. Uji Normalitas}

Berdasarkan uji normalitas yang telah dilakukan dengan menggunakan OneSample Kolmogorov Smirnov Test, didapatkan hasil Asymp. Sig. 0,480 > 0,05 yang menunjukkan bahwa data yang digunakan berdistribusi normal. Hasil uji normalitas dapat dilihat pada tabel 4 lampiran.

b. Uji Multikolinearitas

Berdasarkan pengujian, diperoleh hasil bahwa variabel ROA memiliki nilai tolerance sebesar 0,969 dan nilai VIF sebesar 1,032, variabel CR memiliki nilai tolerance sebesar 0,846 dan nilai VIF sebesar 1,182, variabel DER memiliki nilai tolerance sebesar 0,825 dan nilai VIF sebesar 1,212 dan variabel $\mathrm{ME}$ memiliki nilai tolerance sebesar 0,928 dan nilai VIF sebesar 1,078. Semua nilai tolerance variabel independen yang ada $\geq 0,1$ dan semua nilai Variance Inflation Factor (VIF) yang ada $\leq 10$ sehingga dapat dikatakan bahwa tidak terjadi multikolinearitas. Hasil uji multikolinearitas dapat dilihat pada tabel 5 lampiran.

c. Uji Heteroskedastisitas

Berdasarkan uji heterokedastisitas yang telah dilakukan dengan menggunakan scatter plot, didapatkan hasil bahwa tidak adanya pola yang terbentuk, serta titiktitik yang menyebar diatas dan dibawah angka 0 pada sumbu $\mathrm{Y}$, sehingga dapat dikatakan bahwa tidak terjadi heterokedastisitas. Hasil uji heterokedastisitas dapat dilihat pada tabel 6 lampiran.

d. Uji Autokorelasi

Pengujian ini memerlukan bantuan yang diperoleh dari tabel Durbin-Watson. Berdasarkan pengujian, didapatkan nilai Durbin-Watson sebesar 2,135. Untuk mendapatkan nilai $\mathrm{dL}$ dan dU maka diperlukan $\mathrm{K}$ (jumlah variabel independen) dan $\mathrm{n}$ (jumlah data). Nilai ini berada di antara 1,7245 (dU) dan 2,2755 (4-dU) sehingga dapat dikatakan bahwa tidak terdapat autokorelasi antar variabel independen. Hasil uji autokorelasi dapat dilihat pada tabel 7 lampiran.

\section{Uji F}

Berdasarkan hasil pengujian, diperoleh hasil nilai sig. $0,003<0,05$. Hal ini menunjukkan bahwa terbukti secara bersama- 
sama seluruh variabel independen berpengaruh terhadap variabel dependen. Hasil uji F dapat dilihat pada tabel 8 lampiran.

\section{Uji t}

Berdasarkan pengujian yang terdapat pada tabel 9 lampiran, maka dapat dibentuk persamaan model regresi untuk tahun 20142016 yaitu :

$$
\begin{aligned}
\text { CSRD } & =0,139+0,216 \mathrm{ROA}- \\
0,011 \mathrm{CR}-0,046 \mathrm{DER}+0,147 \mathrm{ME} &
\end{aligned}
$$

Dari persamaan tersebut, dapat dikatakan bahwa dalam kondisi laba cenderung berdampak pada semakin besar pengungkapan tanggung jawab sosial yang dilakukan perusahaan. Sedangkan apabila perusahaan dalam keadaan likuid, perusahaan cenderung enggan melakukan pengungkapan tanggung jawab sosial. Selain itu semakin besar hutang suatu perusahaan menyebabkan perusahaan melakukan pengungkapan tanggung jawab sosial lebih sedikit. Demikian pula dengan media exposure, bila suatu perusahaan mengungkapkan kegiatan CSR pada website, maka cenderung pengungkapan tanggung jawab sosial juga akan semakin luas.

Berdasarkan hasil uji, diperoleh hasil bahwa ROA memiliki nilai sig. sebesar 0,059 $>0,05$. Hasil ini menunjukkan bahwa profitabilitas tidak berpengaruh terhadap luas pengungkapan tanggung jawab sosial.

Berdasarkan hasil uji, diperoleh hasil bahwa CR memiliki nilai sig. sebesar 0,027 < 0,05 . Hasil ini menunjukkan bahwa likuiditas berpengaruh terhadap luas pengungkapan tanggung jawab sosial.

Berdasarkan hasil uji, diperoleh hasil bahwa DER memiliki nilai sig. sebesar 0,078 $>0,05$. Hasil ini menunjukkan bahwa leverage tidak berpengaruh terhadap luas pengungkapan tanggung jawab sosial.

Berdasarkan hasil uji, diperoleh hasil bahwa ME memiliki nilai sig. sebesar 0,0015 $<0,05$. Hasil ini menunjukkan bahwa media exposure berpengaruh terhadap luas pengungkapan tanggung jawab sosial.

\section{Koefisien Determinasi}

Berdasarkan pengujian, diperoleh nilai Adjusted $R$ Square sebesar 0,324 yang menunjukkan bahwa variabel luas pengungkapan tanggung jawab sosial dapat dijelaskan sebesar $32,4 \%$ oleh variabel profitabilitas, likuiditas, leverage, dan media exposure. Akan tetapi, sisanya sebesar $67,6 \%$ dapat dijelaskan oleh variabel lain yang tidak digunakan dalam penelitian ini. Hasil pengujian koefisien determinasi dapat dilihat pada tabel 10 lampiran.

\section{Pembahasan}

1. Pengaruh Profitabilitas terhadap Pengungkapan Tanggung Jawab Sosial

Berdasarkan uji yang dilakukan terhadap variabel profitabilitas (ROA) terhadap pengungkapan CSR didapatkan hasil bahwa profitabilitas tidak berpengaruh terhadap luas pengungkapan tanggung jawab sosial perusahaan yang berarti tolak hipotesis. Hasil uji ini didukung oleh penelitian yang dilakukan oleh Saripudin (2011) yang menyatakan bahwa tidak adanya pengaruh yang signifikan terhadap luas pengungkapan tanggung jawab sosial.

Hasil penelitian ini sesuai dengan teori legitimasi dan juga teori stakeholder yang menyatakan bahwa sistem pengelolaan perusahaan berorientasi pada tidak hanya mencari keuntungan, melainkan juga memperhitungkan faktor sosial sebagai wujud kepedulian dan keberpihakan terhadap masalah sosial kemasyarakatan dan juga berpegang kepada pemegang saham yang merupakan kunci dari berjalannya program sosial yang dimiliki oleh perusahaan. Salah satu alasan yang mendasari kesesuaian teori ini adalah adanya masyarakat yang menjadi kunci bagi kesuksesan perusahaan. Jika tidak ada masyarakat yang menuntut akan adanya pengungkapan, maka diyakini perusahaan tidak akan melakukan pengungkapan dikarenakan adanya biaya tambahan yang cukup besar untuk melakukan pengungkapan tersebut.

Kemungkinan yang mendasari tidak berpengaruhnya profitabilitas terhadap pengungkapan tanggung jawab sosial adalah adanya dorongan dari masyarakat sekitar yang menuntut perusahaan untuk melakukan kegiatan yang berhubungan dengan kepedulian lingkungan. Masyarakat tidak peduli apakah perusahaan memiliki profitabilitas yang tinggi atau rendah, perusahaan wajib untuk melakukan pengungkapan tanggung jawab sosial 
sehingga masyarakat akan merasakan hubungan timbal balik dengan perusahaan.

2. Pengaruh Likuiditas terhadap Pengungkapan Tanggung Jawab Sosial

Berdasarkan uji yang dilakukan terhadap variabel likuiditas (CR) terhadap pengungkapan CSR didapatkan hasil bahwa likuiditas berpengaruh negatif terhadap luas pengungkapan tanggung jawab sosial perusahaan yang berarti terima hipotesis namun memiliki beta yang berbeda. Hasil uji ini didukung oleh penelitian yang dilakukan oleh Silaen (2013) yang menyatakan bahwa likuiditas yang tinggi berpengaruh positif terhadap luas pengungkapan tanggung jawab sosial.

Hasil ini tidak didukung oleh teori stakeholder yang menyatakan bahwa pemegang saham merupakan pemegang kunci dalam jalannya perusahaan dan juga menjadi pengendali dalam hal program sosial yang dibuat oleh perusahaan. Di dalam hal ini, pemegang saham tidak terlalu menjadi penentu dikarenakan minimnya laporan keuangan yang dilaporkan oleh perusahaan sehingga pemegang saham percaya dengan apa yang dilakukan oleh perusahaan.

Hal ini berarti bahwa semakin kuat kondisi keuangan perusahaa $\mathrm{n}$ mengakibatkan semakin sedikit perusahaan melakukan pengungkapan. Hal ini bisa terjadi dikarenakan menurut perusahaan, pengungkapan tidak perlu dilakukan dikarenakan pemegang saham sudah percaya terhadap perusahaan sehingga tidak akan mempengaruhi pengambilan keputusan.

3. Pengaruh Leverage terhadap Pengungkapan Tanggung Jawab Sosial

Berdasarkan uji yang dilakukan terhadap variabel leverage (DER) terhadap pengungkapan CSR didapatkan hasil bahwa leverage tidak berpengaruh terhadap luas pengungkapan tanggung jawab sosial perusahaan yang berarti tolak hipotesis. Hasil uji ini didukung oleh penelitian yang dilakukan oleh Wijaya (2012) yang menyatakan bahwa leverage tidak memengaruhi luas pengungkapan tanggung jawab sosial.

Kemungkinan ini didukung dengan teori keagenan yang menyatakan bahwa adanya hubungan antara manajemen (agent) dengan pemegang saham (principal) sehingga manajemen akan bertindak sesuai dengan cara yang diinginkan para pemegang saham dan juga melaksanakan corporate environmental disclosure. Salah satu alasan yang mendasari kesesuaian teori ini adalah adanya hubungan spesial antara pemegang saham dengan manajemen atau adanya keuntungan tersendiri yang akan didapatkan oleh manajemen jika bertindak sesuai dengan keinginan pemegang saham.

Kemungkinan yang mendasari tidak berpengaruhnya leverage terhadap pengungkapan tanggung jawab sosial adalah perusahaan yang memiliki leverage tinggi tidak dapat menggunakan sumber daya perusahaan dengan maksimal yang nantinya akan digunakan untuk kegiatan sosial dikarenakan adanya resiko besar akan adanya pelanggaran kontrak hutang.

4. Pengaruh Media Exposure terhadap Pengungkapan Tanggung Jawab Sosial

Berdasarkan uji yang dilakukan terhadap variabel media exposure (ME) terhadap pengungkapan CSR didapatkan hasil bahwa media exposure berpengaruh signifikan dan positif terhadap luas pengungkapan tanggung jawab sosial perusahaan yang berarti terima hipotesis. Hasil uji ini didukung oleh penelitian yang dilakukan oleh Wahyutama (2016) yang menyatakan bahwa terdapat hubungan positif antara media exposure terhadap pengungkapan luas tanggung jawab sosial.

Hal ini didukung oleh teori stakeholder dan juga teori legitimasi yang menyatakan bahwa seluruh aktivitas perusahaan ditentukan atas pertimbangan para stakeholder dan juga masyarakat sekitar. Salah satu alasan yang mendasari kesesuaian teori ini adalah dengan adanya pengungkapan melalui media dapat mempermudah stakeholder dalam pengambilan keputusan. Dengan mengkomunikasikan CSR melalui media TV, internet, dan koran, diharapkan dapat membantu masyarakat untuk mengetahui aktivitas sosial yang dilakukan oleh perusahaan. Semakin banyak media yang digunakan oleh perusahaan, maka akan 
semakin luas pula pengungkapan tanggung jawab sosial perusahaan.

\section{Kesimpulan Dan Saran}

\section{Kesimpulan}

Berdasarkan hasil penelitian yang telah dilakukan, diperoleh kesimpulan bahwa terdapat cukup bukti bahwa variabel likuiditas dan media exposure berpengaruh terhadap luas pengungkapan tanggung jawab sosial sedangkan pada variabel profitabilitas dan leverage, tidak terdapat cukup bukti bahwa berpengaruh terhadap luas pengungkapan tanggung jawab sosial.

\section{Saran}

Diharapkan untuk penelitian selanjutnya agar lebih memahami indeks pengungkapan tanggung jawab sosial. Dapat juga untuk menambah jumlah sampel dan periode penelitian serta menambahkan jenis perusahaan yang dapat diteliti. Diharapkan juga untuk penelitian selanjutnya untuk memperluas variabel yang digunakan yang dapat memengaruhi pengungkapan tanggung jawab sosial.

\section{Daftar Pustaka}

Dowling, J., \& Pfeffer, J. (1975). Organizational Legitimacy: Social Values and Organizational Behavior Between the Organizations Seek to Establish Congruence, Vol. 18, No. 1, Hal. 122-136.

Fahmi, F. N. (2015). Pengaruh Ukuran Dewan Komisaris, Profitabilitas, Media Exposure dan Umur Perusahaan Pengungkapan Corporate Social Responsibility (Studi Empiris pada Perusahaan High Profile yang Terdaftar di Bursa Efek Indonesia Tahun 2011-2013).

Fibrianti, N. P. E., \& Wisada, I. G. S. (2015). Pengaruh Hutang, Profitabilitas, dan Tanggung Jawab Lingkungan pada CSR Disclosure Perusahaan Pertambangan, Vol. 2, Hal. 341-355.

Gray, R., Kouhy, R., \& Lavers, S. (1995). Corporate Social and Environmental Reporting: A Review of the Literature and A
Longitudinal Study of UK Disclosure, Accounting, Auditing \& Accountability Journal, Vol. 8, No. 2, Hal. 47-77.

Harahap, S. S. (2001). Teori Akuntansi. Jakarta: PT. Raja Grafindo Persada.

Heny Rahayu (2015). Pesisir Lumajang Rusak Akibat Tambang Liar. https://www.benarnews.org/indonesian/berit a/tambang-pasir-11052015122300.html, di Akses 10 Oktober 2017.

Hummels, H. (1998). Organizing Ethics: A Stakeholder Debate, Journal of Business Ethics, Vol. 17, Hal 1403-1419.

Initiative, G. R. (2013). Sustainability Reporting Guidelines.

Jensen, M. C., \& Meckling, W. H. (1976). Theory of the Firm: Managerial Behavior, Agency Costs and Ownership Structure, Vol. 3, Hal. 305-360.

Kamil, A., \& Herusetya, A. (2012). Pengaruh Karakteristik Perusahaan Terhadap Luas Pengungkapan Kegiatan Corporate Social Responsibility, Media Riset Akuntansi, Vol. 2, No. 1, Hal. 1-17.

Maiyarni, R., Erwati, M., \& Susfayetti (2014). Pengaruh Profitabilitas, Ukuran Perusahaan, Likuiditas, dan Leverage Terhadap Pengungkapan Corporate Social Responsibility (CSR) pada Perusahaan LQ45 yang Terdaftar di Bursa Efek Indonesia Periode 2009-2012, Jurnal Cakrawala Akuntansi, Vol. 6, No. 1, Hal. 79-94.

Merakati, D. (2016). Pengaruh Profitabilitas Terhadap Pengungkapan Corporate Social Responsibility (CSR) pada Perusahaan Manufaktur yang Terdaftar di Bursa Efek Indonesia (BEI).

Nur, M., \& Priantinah, D. (2012). Analisis FaktorFaktor yang Mempengaruhi Pengungkapan CSR di Indonesia (Studi Empiris pada Perusahaan Berkategori High Profile yang Listing di Bursa Efek Indonesia), Jurnal Nominal, Vol. 1, No. 1, Hal. 1-13. 
Republik Indonesia. (1967). Undang-Undang No. 11 Tahun 1967 tentang Pokok-Pokok Pengusahaan Pertambangan. Sekretariat Negara. Jakarta.

(2007). Undang-Undang No 40 Tahun 2007 tentang Perseroan Terbatas. Sekretariat Negara. Jakarta.

Reverte, C. (2009). Determinants of Corporate Social Responsibility Disclosure Ratings by Spanish Listed Firms, Journal of Business Ethics, Vol. 88, No. 2, Hal. 351-366.

Rindawati, M. W. (2015). Pengaruh Profitabilitas, Ukuran Perusahaan, Leverage, dan Kepemilikan Publik Terhadap Pengungkapan Corporate Social Responsibility (CSR), Jurnal Ilmu \& Riset Akuntansi, Vol. 4, No. 6, Hal. 2-15.

Rokhlinasari, S. (2016). Teori-Teori dalam Pengungkapan Informasi Corporate Social Responsibility Perbankan, Vol. 7, No. 1, Hal. $1-11$.

Saripudin (2011). Pengaruh Size Perusahaan, Profitabilitas, Tipe Industri dan Ukuran Dewan Komisaris Terhadap Pengungkapan Corporate Social Responsibility (Studi Empiris pada Perusahaan Industri di Bursa Efek Indonesia Tahun 2009).

Sembiring, E. R. (2005). Karakteristik Perusahaan dan Pengungkapan Tanggung Jawab Sosial: Studi Empiris pada Perusahaan yang Tercatat di Bursa Efek Jakarta. Simposium Nasional Akuntansi VIII, Hal. 379-395.

Silaen, B. M. (2013). Analisis Pengaruh Size Perusahaan, Tipe Industri, Basis Perusahaan, Profitabilitas, Leverage, dan Likuiditas Terhadap Tingkat Pengungkapan Sosial pada Perusahaan yang Go Public di BEI 2010, Jurnal Akuntansiku, Vol. 1, No. 1.
Soraya, E. (2016). Pengaruh Profitabilitas, Likuiditas, Sales Growth, dan Media Exposure Terhadap Pengungkapan Tanggung Jawab Sosial Perusahaan.

Tamba, E. G. H. (2011). Pengaruh Struktur Kepemilikan Terhadap Pengungkapan Tanggung Jawab Sosial Perusahaan (Studi Empiris pada Perusahaan Manufacturing Secondary Sectors yang Listing di BEI Tahun 2009).

Untung, H. B. (2009). Corporate Social Responsibility. Jakarta: Sinar Grafika.

Wahyutama, N. R. I. (2016). Pengaruh Ukuran Perusahaan, Profitabilitas, Leverage, dan Media Exposure Terhadap Corporate Social Responsibility Disclosure. Artikel Ilmiah Mahasiswa 2016 Universitas Jember, Hal. 18.

Wibisono, Y. (2016). Membedah Konsep \& Aplikasi CSR. Gresik: Fascho Publishing.

Wijaya, M. (2012). Faktor-Faktor yang Mempengaruhi Pengungkapan Tanggung Jawab Sosial pada Perusahaan Manufaktur yang Terdaftar di Bursa Efek Indonesia. Jurnal Ilmiah Mahasiswa Akuntansi, Vol. 1, No. 1, Hal. 26-30.

Yuliansyah, R. F. (2017). Pengaruh Profitabilitas, Likuiditas, Growth, Media Exposure, dan Umur Perusahaan Terhadap Pengungkapan Corporate Social Responsibility (CSR) (Studi Empiris Perusahaan Manufaktur di BEI Tahun 2013-2015). 


\section{LAMPIRAN}

Tabel 1

Daftar Sampel Perusahaan

\begin{tabular}{|c|l|c|}
\hline No & \multicolumn{1}{|c|}{ Nama Perusahaan } & Kode \\
\hline 1 & PT. Aneka Tambang (Persero) Tbk & ANTM \\
\hline 2 & PT. Ratu Prabu Energi Tbk & ARTI \\
\hline 3 & PT. Cita Mineral Investindo Tbk & CITA \\
\hline 4 & PT. Citatah Tbk & CTTH \\
\hline 5 & PT. Central Omega Resources Tbk & DKFT \\
\hline 6 & PT. Elnusa Tbk & ELSA \\
\hline 7 & PT. Mitra Investindo Tbk & MITI \\
\hline 8 & PT. Perdana Karya Perkasa Tbk & PKPK \\
\hline 9 & PT. Tambang Batubara Bukit Asam (Persero) Tbk & PTBA \\
\hline 10 & PT. Radiant Utama Interinsco Tbk & RUIS \\
\hline 11 & PT. Golden Eagle Energy Tbk & SMMT \\
\hline 12 & PT. Timah (Persero) Tbk & TINS \\
\hline
\end{tabular}

Tabel 2

Hasil Uji Statistik Deskriptif

Descriptive Statistics

\begin{tabular}{|l|r|r|r|r|r|}
\hline & $\mathrm{N}$ & Minimum & Maximum & Mean & Std. Deviation \\
\hline CSRD & 36 & .0440 & .5934 & .155983 & .1503716 \\
ROA & 36 & -.7842 & .1363 & -.032186 & .1578043 \\
CR & 36 & .2656 & 20.1675 & 2.587411 & 4.0746654 \\
DER & 36 & .0425 & 3.5614 & .992155 & .7333369 \\
ME & 36 & 0 & 1 & .67 & .478 \\
Valid N (listwise) & 36 & & & & \\
\hline
\end{tabular}


Tabel 3

Hasil Uji Kesamaan Koefisien (Pooling)

Coefficients $^{\mathrm{a}}$

\begin{tabular}{|l|r|r|r|r|r|}
\hline \multirow{2}{*}{ Model } & \multicolumn{2}{|c|}{ Unstandardized Coefficients } & \multicolumn{1}{c|}{$\begin{array}{c}\text { Standardized } \\
\text { Coefficients }\end{array}$} & \multicolumn{1}{c|}{ Sig. } \\
\cline { 2 - 4 } & \multicolumn{1}{|c|}{ B } & \multicolumn{1}{|c|}{ Std. Error } & \multicolumn{1}{c|}{ Beta } & \\
\hline (Constant) & .127 & .113 & & 1.126 & .273 \\
ROA & .520 & .729 & .546 & .713 & .484 \\
CR & -.009 & .010 & -.235 & -.830 & .416 \\
DER & -.024 & .045 & -.118 & -.540 & .595 \\
ME & .098 & .120 & .312 & .819 & .422 \\
D1 & -.032 & .229 & -.101 & -.139 & .891 \\
D2 & .105 & .170 & .334 & .618 & .543 \\
D1_ROA & .198 & 1.071 & .049 & .185 & .855 \\
D1_CR & .028 & .064 & .163 & .444 & .662 \\
D1_DER & -.023 & .115 & -.083 & -.200 & .844 \\
D1_ME & .035 & .154 & .099 & .230 & .820 \\
D2_ROA & -.347 & .750 & -.339 & -.462 & .649 \\
D2_CR & -.009 & .014 & -.196 & -.600 & .555 \\
D2_DER & -.110 & .110 & -.387 & -1.003 & .327 \\
D2_ME & .087 & .148 & .243 & .585 & .565 \\
\hline
\end{tabular}

a. Dependent Variable: CSRD

Tabel 4

Hasil Uji Normalitas

One-Sample Kolmogorov-Smirnov Test

\begin{tabular}{|ll|r|}
\hline & & RES_2 \\
\hline N & & 36 \\
Normal Parameters ${ }^{\mathrm{a}, \mathrm{b}}$ & Mean & $0 \mathrm{E}-7$ \\
& Std. Deviation & .11636478 \\
& Absolute & .140 \\
Most Extreme Differences & Positive & .140 \\
& Negative & -.070 \\
Kolmogorov-Smirnov Z & & .840 \\
Asymp. Sig. (2-tailed) & & .480 \\
\hline
\end{tabular}

a. Test distribution is Normal.

b. Calculated from data. 
Tabel 5

Hasil Uji Multikolinearitas

Coefficients $^{a}$

\begin{tabular}{|c|c|c|c|c|c|c|c|c|}
\hline \multirow{2}{*}{\multicolumn{2}{|c|}{ Model }} & \multicolumn{2}{|c|}{$\begin{array}{c}\text { Unstandardized } \\
\text { Coefficients }\end{array}$} & \multirow{2}{*}{$\begin{array}{c}\text { Standardized } \\
\text { Coefficients } \\
\text { Beta } \\
\end{array}$} & \multirow[t]{2}{*}{$\mathrm{t}$} & \multirow[t]{2}{*}{ Sig. } & \multicolumn{2}{|c|}{ Collinearity Statistics } \\
\hline & & $\mathrm{B}$ & Std. Error & & & & Tolerance & VIF \\
\hline \multirow{5}{*}{1} & (Constant) & .139 & .056 & & 2.487 & .018 & & \\
\hline & ROA & .216 & .135 & .227 & 1.606 & .118 & .969 & 1.032 \\
\hline & CR & -.011 & .006 & -.302 & -2.000 & .054 & .846 & 1.182 \\
\hline & DER & -.046 & .031 & -.223 & -1.454 & .156 & .825 & 1.212 \\
\hline & ME & .147 & .045 & .468 & 3.240 & .003 & .928 & 1.078 \\
\hline
\end{tabular}

a. Dependent Variable: CSRD

Tabel 6

Hasil Uji Heteroskedastisitas

Scatterplot

Dependent Variable: CSRD

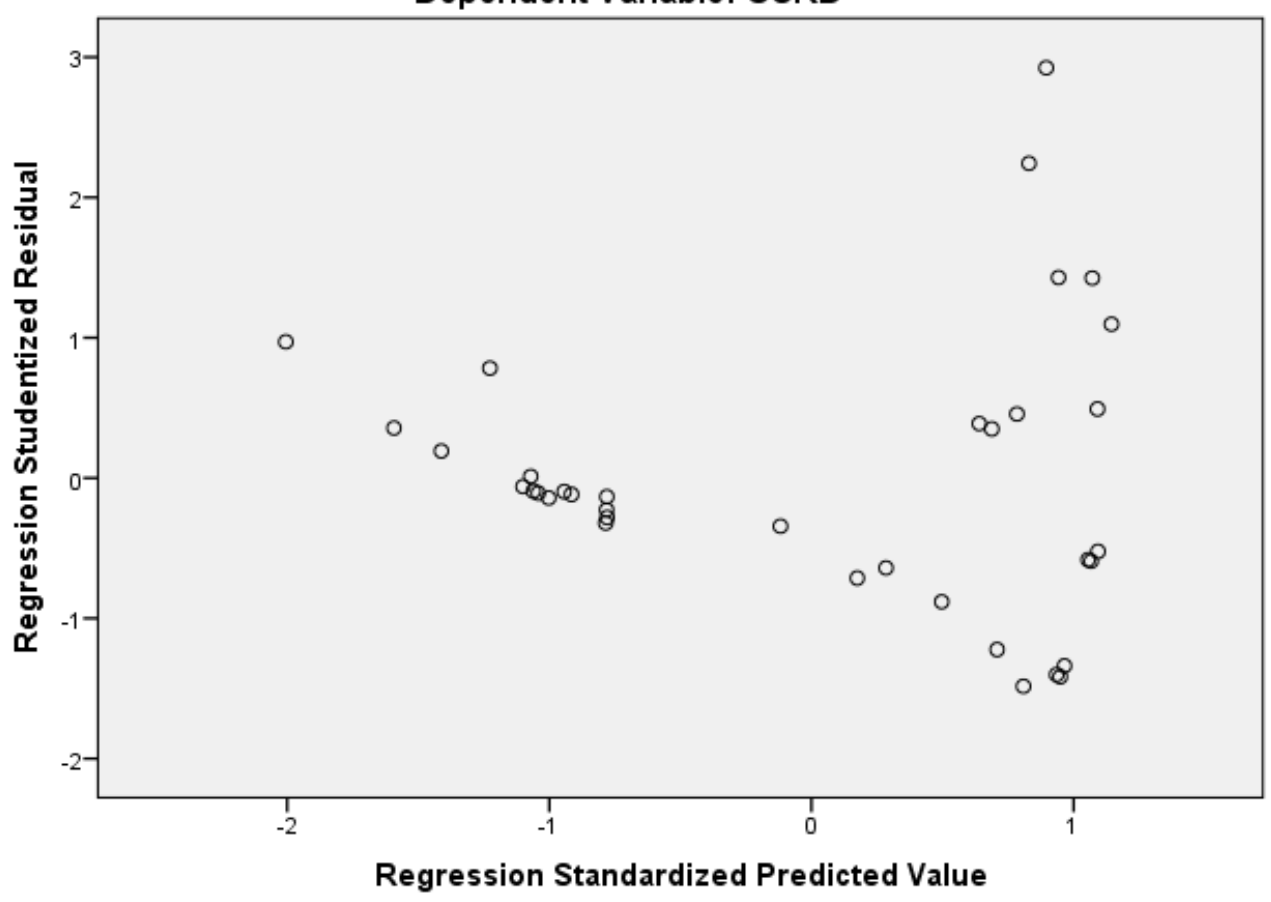


Tabel 7

Hasil Uji Autokorelasi

Model Summary

\begin{tabular}{|l|r|r|r|r|r|}
\hline Model & $\mathrm{R}$ & $\mathrm{R}$ Square & \multicolumn{1}{|c|}{$\begin{array}{c}\text { Adjusted R } \\
\text { Square }\end{array}$} & $\begin{array}{c}\text { Std. Error of the } \\
\text { Estimate }\end{array}$ & Durbin-Watson \\
\hline 1 & $.633^{\mathrm{a}}$ & .401 & .324 & .1236445 & 2.135 \\
\hline
\end{tabular}

a. Predictors: (Constant), ME, CR, ROA, DER

b. Dependent Variable: CSRD

Tabel 8

Hasil Uji F

ANOVA $^{\mathrm{a}}$

\begin{tabular}{|rl|r|r|r|r|r|}
\hline \multicolumn{1}{|l|}{ Model } & Sum of Squares & df & Mean Square & F & Sig. \\
\hline & Regression & .317 & 4 & .079 & 5.192 & $.003^{\mathrm{b}}$ \\
1 & Residual & .474 & 31 & .015 & & \\
& Total & .791 & 35 & & & \\
\hline
\end{tabular}

a. Dependent Variable: CSRD

b. Predictors: (Constant), ME, CR, ROA, DER

Tabel 9

Hasil Uji t

Coefficients $^{a}$

\begin{tabular}{|c|c|c|c|c|c|c|}
\hline \multirow{2}{*}{\multicolumn{2}{|c|}{ Model }} & \multicolumn{2}{|c|}{ Unstandardized Coefficients } & \multirow{2}{*}{$\begin{array}{c}\text { Standardized } \\
\text { Coefficients } \\
\text { Beta }\end{array}$} & \multirow[t]{2}{*}{$\mathrm{t}$} & \multirow[t]{2}{*}{ Sig. } \\
\hline & & B & Std. Error & & & \\
\hline \multirow{5}{*}{1} & (Constant) & .139 & .056 & & 2.487 & .018 \\
\hline & ROA & .216 & .135 & .227 & 1.606 & .118 \\
\hline & $\mathrm{CR}$ & -.011 & .006 & -.302 & -2.000 & .054 \\
\hline & DER & -.046 & .031 & -.223 & -1.454 & .156 \\
\hline & ME & .147 & .045 & .468 & 3.240 & .003 \\
\hline
\end{tabular}

a. Dependent Variable: CSRD 
Tabel 10

Hasil Koefisien Determinasi

Model Summaryb

\begin{tabular}{|l|r|r|r|c|}
\hline Model & $\mathrm{R}$ & $\mathrm{R}$ Square & \multicolumn{1}{c|}{$\begin{array}{c}\text { Adjusted R } \\
\text { Square }\end{array}$} & $\begin{array}{l}\text { Std. Error of the } \\
\text { Estimate }\end{array}$ \\
\hline 1 & $.633^{\mathrm{a}}$ & .401 & .324 & .1236445 \\
\hline
\end{tabular}

a. Predictors: (Constant), ME, CR, ROA, DER

b. Dependent Variable: CSRD 